\title{
The Sensible and Identity Crisis of Healthcare Workers: The Perspective of Physiotherapists Practicing Fasciatherapy
}

\author{
Christian Courrauda, Anne Lieutauda, Danis Bois ${ }^{b}$
}

\begin{abstract}
The identity of paramedic professions is bound to develop in order to adapt to the changes of the world of health. Careproviders' identity is based on the interpersonal dimension, yet French massage-physiotherapy bases this interpersonal competence on touch. This is why many practitioners try to develop this aspect of their practice through continuing professional education. Danis Bois Method (Méthode Danis Bois: MDB) of fasciatherapy, characterized by its relational and sensitive approach to care and touch, stands in this field. This paper will present the impacts of this manual therapy on the professional identity of 446 masseurs-physiotherapists who took part in a self-assessment survey. The results show that, in spite of the few difficulties they meet within their duties, practicing fasciatherapy integrates perfectly well into the framework of massage-physiotherapy. It largely reinforces the feeling of therapeutical efficacy and the capacity to meet the evolution in health needs (chronic diseases, mental suffering, and patients' quality of life). It also restores meaning and value to the profession and boosts motivation as well as it fosters the congruence of both personal and professional identities. It is thus considered as an added value to masso-physiotherapy, a means to accomplish oneself and an essential component of professional identity.
\end{abstract}

\section{Keywords}

Danis Bois Method fasciatherapy, professionnal identity, physiotherapy, crisis of healthcare workers, sociological inquiry

Every trade and every profession build a particular professional identity. Every single profession has its own. Two notions constitute the careproviders' identity: "curing" whose curative aim is centred on symptoms and their healing; and "caring", centred on the patient and the attention given to others, their values, their fundamental needs, and their well-being. Although distinct in their definitions and their aims, they have to coexist within the practice of careproviding (Laemmlin-Cencig 2015; Piguet 2010; Tronto 1993; Honoré 2003; Hesbeen 1997). Being a careprovider entails having and developing together and in harmony professional gestures (techniques and prescribed acts) and professional behaviours (attentiveness, receptiveness, and presence).

This identity is today jeopardized in a changing context of care and health. As a matter of fact, these identites, constructed on fighting diseases with an

aCentre for Applied Research and Study in Perceptional Psychoeducation/University Fernando Pessoa (CERAP/UFP), Portugal

bUniversity Fernando Pessoa (UFP), Portugal

Correspondent Author:

Christian Courraud, 63 Boulevard Berthelot, 63000, Clermont-Ferrand, France 
emphasis on the curing dimension, are regularly losing their landmarks when confronted to their inability and powerlessness to cure patients with chronic diseases: "A disease can take on many phases, many faces. It fools the opponent and defies the emergency cure pattern which is the basis of the careproviders' identities. These 'damaged' identities make reorganization both complicated and essential” (Rothier-Bautzer 2002: 44).

These destabilizations produce identity crises which often favour a new awareness of the discrepancy between professional reality as lived and the professional ideal. The careproviders feel that their initial professional education has not prepared them to respond to reality and complex caregiving situations. As they question the very sense of their profession which no longer fulfills its existential function, some careproviders experience a real physical as well as psychological suffering which can lead them to professional exhaustion (burn-out): "Their deep disappointment under the seal of a damaged ideal is a sign of their irrealistic expectations and challenges their relationship to work as a major pathway to self-fulfiment and self-representation" (Daloz 2007: 84).

These new careproviding situations strongly revive the importance of going back to a caring relationship presented by some writers as the founding principle of the caregivers' identity: "The relationship with patients remains, (...) the consistant specificity of care-related professions even though it is professionalized" (Holcman 2006: 37). However, this implies that the careproviders turn to themselves to discover their own sensitive relationship to themselves and to others:

The emergence of patients subjects of their own health can take place within the framework of the caring relationship (?)providing the instructor-careprovider accepts to be touched as a person by the person who is in front of him. Indeed educating a person cannot be done without accepting to go within oneself in a transformation process. (Lasserre-Moutet et al. 2008: 92)
A new identity pattern harmoniously combining curing and taking care of must also emerge and it represents a major issue of careproviders' initial and continuing professional education. The construction of this new identity form is a stake to prevent suffering at work, support self-fulfillment as well as professional achievement, and improve the quality and efficacy of careproviding.

\section{PRACTICING MASSAGE-PHYSIOTHERAPY IN FRANCE}

In 2013, the total number of French masseurs-physiotherapists (Masseurs-Kinésithérapeutes $=$ MK) was estimated at 77,778. They were mainly men (51\%) with an average age of 41 (Sicard 2013). They are preferably self-employed $(79 \%$ of the population) either under NHS (National Health System) contract (with effective care refund to the patients) or out of NHS contract (patients do not get any refund). Within the usual practice, the standard duration of a session is 30 minutes. However, the practice can take various and heterogenous forms whether the practitioner tailors his physiotherapy to one patient at a time or takes many patients together (three to four, even more in case of group activities) (Matharan, Micheau, and Rigal 2009).

Different surveys conducted with masseurs-physiotherapists (Groupe Pasteur Mutualité 2001; CARPIMKO 2008; CNOMK 2009; 2010) show that they are very attached to their job on the essential account of their commitment to cure people. They also consider that the French have a good image of them and that their place in society is significant. However, they think that their profession has become more difficult to practice mainly because of an overwhelming paper workload and of the patients' growing expectations. They are under the impression of being clearly overloaded with work, which reduces recovery time and affects their practice and their family activities negatively. Lastly as for other health 
professionals, their lack of confidence in the future can be underlined.

Surveys also reveal some discontent concerning their initial education which does not seem to prepare them correctly to self-employment practice (Matharan et al. 2009; CNOMK 2009). They resort to continuing professional education to make up for the lacks but also "to meet their patients' identified needs" or "to expand their scope or broaden their knowledge of a domain”. For some, continuing education could also be an opportunity to commit themselves to long studies (such as osteopathy) which will lead them to a private practice or even a total change of job (Matharan et al. 2009).

Finally, massage-physiotherapy, just like all the other health professions, must adapt to cope with the growing evolution of chronic diseases by moving from an exclusively biomedical pattern to a global health pattern, that is to say, a "patient-centred" pattern (Gatto 2005). This new conception of care implies that masseurs-physiotherapists strain to provide global (biophysiological, psychological, social, and cultural components) and complex care, integrating educational and interpersonal competences. The physiotherapists who see themselves mainly as therapists are thus led to define their way of perceiving and conceiving their duties and their job (Matharan et al. 2009).

\section{TOUCH AT THE HEART OF THE FRENCH MASSEUR-PHYSIOTHERAPIST IDENTITY}

In France, massage-physiotherapy stands out from other health professions since care is performed through and by touch: "Longer and more frequently than medical doctors and nurses, physiotherapists as body practitioners play an interface, mediation and service-providing role altogether whenever hands are the essential tool in the therapeutical relation" (Monet 2011: 7). To assess the significance of touch, it must be kept in mind that France is the only country in the world to use the word "masseur" next to "physiotherapist" in the job title. Other countries have adopted the words "physiotherapy" and "physiotherapist".

For some practitioners, touch is the very heart of their job because it implies giving time and attention to patients while bringing them more pleasure and satisfaction: "This double contact, tactile and psycho-social is perceived as the heart of the practice: knowing how to listen to people and find the right gesture to cure them" (Matharan et al. 2009: 66). They see it as a means to take global care of the person's body and mind:

This contact, both effective and relational, is at the very heart of the passion for this job. Massaging is, according to the practitioners, a diagnostic tool as well as a therapy. It is a physiological therapy for a lot of pathologies but also a psychological therapy for all of them. Patients are eager to receive this body care which is by construction a care of Self. (Matharan et al. 2009: 6)

The great number of masseurs-physiotherapists who try to enhance their professional education with manual therapy (manual lymphatic drainage, microphysiotherapy, manual therapy, fasciatherapy, osteopathy, and well-being massages) illustrates how valuable touch is. Many of them claim that touch has become their specialty (CNOMK 2009). It shows how going deeper into this field of practice is a priority for a large number of physiotherapists.

\section{SENTIENCE AND DANIS BOIS' FASCIATHERAPY METHOD (DBM-METHODE DANIS BOIS = MDB)}

The word sentient (Bois and Austry 2007) lies within the same line as phenomenology and humanist psychology paradigms which place perception and body experience as the most important elements in relating to oneself. The fundamental project is to place the subject back to the centre of his own existence and 
to enable him to experience himself through a situation which draws on perceptive potentiality. The sentient subject builds himself from, in, and through a body experience in order to acknowledge himself as a perceiving, feeling, and thinking being (Aumonier 2017; Gauthier 2015; Florenson 2012; Humpich and Lefloch-Humpich 2008). This approach considers that one of the essentiel crises of our present modern world is rooted in the absence of the subject to himself. The subject does not feel nor perceive himself and lives estranged from his feeling of existence.

The various researches conducted at the CERAP (Centre for Applied Research and Study in Perceptual Psychoeducation) explore the applications of this formative approach of human beings to the fields of care, training, biographical process, the support to changes, arts, and expressiveness. Studies have proved the contribution of this form of relationship to oneself in crises situations such as going through a professional change and undergoing adult training (Marchand 2015; Dagot 2013; Bois 2007), experiencing an illness (Dupuis 2016; Bertrand et al. 2017; Angibaud 2013; Duval, Duprat, and Berger 2013; Bois, Bourhis, and Berger 2010), or even supporting changes (Cousin 2016; Laemmlin-Cencig 2015).

Among the different methods used to help this sentient dimension of the subject emerge and actualize, we find the touch of contact. This touch allows to create and set a reciprocity relationship between the practitioner and the supported patient, a non-verbal, organic relationship helping the patient's return to himself (Austry and Berger 2014; Bourhis and Bois 2012; Courraud 2007).

Qualitative studies conducted at the CERAP (Cusson 2015; Bourhis 2012) have shown that learning this touch develops perceptive-cognitive resources (an ability to perceive and evaluate internal information) and enriches the interpersonal abilities (quality of presence and attention to oneself and to others, accuracy of the touch, and ability to meet body's requirements). This touch can also provoke a new awareness in ways of being in the relation such as lack of self-confidence, tendency to control, and attentional difficulty to get physically and psychologically involved (Bourhis 2012). MDB (Méthode Danis Bois) fasciatherapy introduces this sentient dimension in the care relationship and its learning process is integrated in the clinical approach.

\section{DBM FASCIATHERAPY AND MASSAGE-PHYSIOTHERAPY}

Elaborated in the 80s by D. Bois (first an osteopath and physiotherapist and later a doctor in Education Science) from the leading ideas of osteopathy, DBM (Danis Bois Method) fasciatherapy has moved away from it by its global somatic and psychological approach of the patient and by the integration of a touch of contact in the therapeutical act: "In fact, DBM fasciatherapy differs from classical fasciatherapy by the fact that it concerns the somatopsychic dimension of the person through its very distinctive touch of contact” (Rosier 2013: 37). The definition of fasciatherapy has gradually come closer to the field of humanist therapies which place the patient at the centre of the curing process:

Fasciatherapy is a global manual therapy centred on the patient. It is curative, relational and educational. The therapeutical gesture combines a clinical and interpersonal dimension which makes this manual approach original in the field of manual therapies. The physiotherapist finds a global approach in fasciatherapy which addresses the fascia and also the body-mind unit. (Courraud and Quéré 2010: 14)

This conception of care seems to meet the expectations of some masseurs-physiotherapists who are trying to develop different aspects of their touch as the authors mentioned it earlier.

In France, DBM fasciatherapy has been part of the massage-physiotherapy practices for over 30 years and has been mentioned in some surveys as a "particular way of exercising” physiotherapy (CNOMK 2009). It 
is applied by masseurs-physiotherapists in the care for complicated pathologies such as lower back pains (Trudelle 2003), anxiousness (Convard 2013; Payrau et al. 2015), fibromyalgia (Dupuis 2016) or sports practices (Lambert 2013; Rosier 2013). However, this approach is not acknowledged by the French masso-physiotherapy authorities as a specificity, a specialism, or a title (CNOMK 2012) because like osteopathy from where it stems, it falls in with the paradigm of complementary non-conventional medicines. This particular position runs counter to the recent growing interest of conventional medicine which considers that the treatment of fascias presents a real relevance in treating physical and even psycho-emotional pathologies (Kwong and Findley 2014; Simmonds, Miller, and Gemmell 2012; Schleip and Jäger 2012).

This current survey intends to study the impacts of fasciatherapy in the specific field of French massage-physiotherapy. As a matter of fact, the authors thought it relevant to understand why some masseurs-physiotherapists are interested in this approach and up to what point it helps them meet the new requirements of their profession's evolution. This survey aims at:

(1) Identifying the contribution of fasciatherapy to the various aspects of massage-physiotherapy practice;

(2) Identifying the impacts of fasciatherapy on the framework of massage-physiotherapy practice and on the perception of the profession;

(3) Estimating how fasciatherapy helps masseurs-physiotherapists adapt to the requirements of their profession.

\section{EQUIPMENT AND METHOD}

The authors conducted a survey in the form of a self-assessment questionnaire (between February 13 and April 15, 2013) with a population of 446 French masseurs-physiotherapists trained in DBM fasciatherapy (Courraud 2015).
The sample was built from the Association Nationale des Physiotherapeutes (ANKF) data base and Point d'Appui Society (MDB fasciatherapy training center), the only sources able to supply the authors with a group of French physiotherapists trained to MDB fasciatherapy, sharing the same practice and similar training and professional experience conditions in this practice. The concerned practitioners had to have achieved at least one year of MDB training.

From an ethical point of view, the surveyed were notified of the topic of the survey, the context of the research, and the identity of its author before any connexion to the questionnaire. Their anonymity was guaranteed from their recruitment. Then when they connected to the survey questionnaire, a statement had to be approved by the participants to enable them to carry on. They had to confirm they had been seriously informed that they felt free to answer honestly and to accept that their answers would be included in this doctorate research work.

Lastly, this survey about the practitioners' experiences and exercising conditions in their usual framework, in so far as the deontological rules usually linked to social surveys was respected (recruiting mode, honesty of the collect work, transparency on the survey and its objectives, and security of the data); the authors did not think it necessary to submit it to an ethic commission.

The tailored questionnaire consisted of 72 questions divided into four themes related to professional identity (the profile, the changes, the identification, and the enrichments). To carry out this paper, the authors selected only the questions concerning:

(1) The motivation to undergo the fasciatherapy training (multiple choice questions with a maximum of three answers) as well as the easiness/difficulty degree to relate fasciatherapy to physiotherapy (Likert scale from 1 "very difficult" to 4 "very easy");

(2) The mode of practicing fasciatherapy and its application in physiotherapy: numbers of sessions per 
day (one possible answer), length of a session (one possible answer), the part of practice dedicated to fasciatherapy (one possible answer), and the application conditions of fasciatherapy in a physiotherapy session (multiple answers);

(3) The impacts of fasciatherapy practice on professional exercise: modifications of the exercise framework and of clients, development of new domains of exercise, and impacts on further training;

(4) The contribution of fasciatherapy on manual touch (one possible answer), interpersonal qualities (multiple answers), professional competences (therapeutical efficiency, relationship to patients, and pedagogical competences), and domains of care (physical pain, psychological suffering, acute and chronical pathologies, and quality of life and well-being). These two questions use the Likert scale (from 1 "no improvement" to 4 "very significant improvement") and on the pathologies which were the most and the least improved (open questions with compulsory answer required, possibility to answer "none" and to quote a maximum of six diseases);

(5) The different impacts of practicing fasciatherapy on professional life (conception of exercising fasciatherapy, influence on professional life, consequences on professional life, and impacts on health) from a Likert scale (from 1 "don't agree at all” to 4 "agree totally");

(6) The perception of professional identity through three possible ways of answering (one possible answer): physiotherapist, physiotherapist-fasciatherapist, and fasciatherapist. The one based on the way the respondents present themselves professionally comprised four possibilities (one possible answer): physiotherapist, physiotherapist-fascatherapist, fasciatherapist, or other.

The data were then analyzed thanks to Modalisa softwares (Kynos 2012) and SPSS 22.0. The survey which produced the data had an exploratory value so the analyses were conducted with descriptive statistics, mainly frequency functions (numbers, percentages, modes, medial zones, and cumulated frequencies). As for the variables using Likert scales, the authors compared the answers with analysis of variance (ANOVA). For the questions requiring ranking, the authors chose to represent the results corresponding to choice 1 (or answer ranking 1 ). The written answers to the open questions were treated with new wording to gather the diversity of answers in wider themes.

\section{RESULTS}

\section{Profile of the Surveyed Population}

The surveyed population is different from the reference population as there are far more women $(\mathrm{n}=$ 154, $65 \%$ to $49 \%$, source: Sicard 2013). The most represented age group is between 30 and 44 years old ( $\mathrm{n}=105,44 \%)$.

The authors' sample is almost entirely composed of masseurs-physiotherapists working in private practices $(n=220,92 \%)$ and predominantly under contract $(n=149,62.6 \%)$ even if a rather signifiant number of them develop another activity without contract ( $\mathrm{n}=51,21.4 \%)$. This cannot be compared to the reference group. They tend to work more in group practices $(n=114,47.9 \%)$ than in private offices $(n=$ $100,42 \%)$, which is more than the reference population (29\%, source: Sicard 2013).

This group has a significant experience of both masso-physiotherapy (average of 20 years, +/- 11 years) and fasciatherapy (average of 12 years, +/- 8 years). Besides, the majority of the group sample $(\mathrm{n}=$ 208, 87.4\%) have a professional certification in fasciatherapy.

The vast majority of the surveyed people have been trained to other complementary physiotherapy approaches $(\mathrm{n}=144,60.5 \%)$ and claim that they practice one or several specializations within their activity ( $\mathrm{n}=193,81.1 \%$ ) mainly in the field of manual therapy $(\mathrm{n}=167,70.2 \%)$. 


\section{Motivation for Fasciatherapy}

Among the motivations of the masseurs-physiotherapists to follow a fasciatherapy training (multiple choice questions with maximum three answers), the improvement of therapeutical efficacy seems decisive $(n=183,76.9 \%)$ ahead of seeking for a care for somatopsychic unit ( $\mathrm{n}=125$, $52.5 \%$ ) and the development of the interpersonal dimension of their touch $(\mathrm{n}=118,49.6 \%)$. Looking for a global manual therapy $(n=93,39.1 \%)$ and even more a care for patients' psychology $(\mathrm{n}=16,6.7 \%)$ seem less important. Few masseurs-physiotherapists start fasciatherapy training to change jobs $(n=4,1.7 \%)$ but the longing for self-fulfilment $(n=65,27.3 \%)$ and the quest for a new professional motivation ( $\mathrm{n}=51$, 21.4\%) seem to constitute important motives to start this training.

\section{Practicing Fasciatherapy}

Most people in the group sample $(n=194,81.5 \%)$ dedicate more than half of their professional activity to fasciatherapy. The analysis of the number of fasciatherapy sessions performed daily gives an insight of this practice: more than the sample's half (n $=139,58.4 \%$ ) perform from five to 10 or more sessions per day. A smaller part $(n=66,27.7 \%)$ perform between one and five sessions per day while an even smaller number perform one or less than one session per day.

A fasciatherapy session usually lasts more than 30 minutes $(\mathrm{n}=189,79.3 \%)$ with a tendency to last longer than 45 minutes ( $n=128,53.7 \%$ ). Only a small number manage to practice fasciatherapy within the conventional time framework, that is to say, 30 minutes at the most $(n=49,20.6 \%)$.

The application of fasciatherapy within the exercise of physiotherapy is done according to three modes: mainly separating fasciatherapy from the physiotherapy sessions ( $\mathrm{n}=107,44.9 \%)$ and applying it in or outside a physiotherapy session $(n=94$,
39.5\%). Only a small part apply it exclusively in the physiotherapy sessions ( $\mathrm{n}=37,15.9 \%)$. Finally, a large majority of practitioners $(n=174,73 \%)$ tend to practice fasciatherapy in an exclusive way without resorting to other techniques.

\section{How the Link Between Fasciatherapy and Physiotherapy Is Perceived}

The majority of the population think that it is easy (n $=130,54.6 \%)$ even very easy $(n=61,25.6 \%)$ to integrate fasciatherapy into physiotherapy practice. Only a small part $(\mathrm{n}=47,19.7 \%)$ think that it is difficult $(n=40,16.8 \%)$ even very difficult $(n=7$, $2.9 \%$ ) to link the two approaches.

The majority of the population $(n=150,63 \%)$ consider fasciatherapy as a part of physiotherapy: most see it rather as a specialization in their job ( $\mathrm{n}=76,31.9 \%)$, others as a "competence" $(\mathrm{n}=50$, $21 \%)$ and in a more subdued way as a "complement" $(\mathrm{n}=24,10.1 \%)$. A significant part $(\mathrm{n}=88,37 \%)$ consider however that fasciatherapy is a profession on its own and distinguish it from physiotherapy.

A large proportion $(n=148,62.2 \%)$ generally agree to say that practicing fasciatherapy is practicing physiotherapy. As a consequence, 37.8\% ( $\mathrm{n}=90)$ disagree with this statement, and $13 \%(n=31)$ reject it entirely (“don’t agree at all”).

The difficulties encountered to apply fasciatherapy (see Figure 1) are mainly linked to the conventional physiotherapy practice framework. For instance, the duration of a physiotherapy session is too short ( $\mathrm{n}=$ 48, 20.2\%) and its rate/cost is insufficient ( $\mathrm{n}=43$, $18.1 \%)$. Even more important is that fasciatherapy is not acknowledged by the profession ( $\mathrm{n}=55,23.1 \%$ ). The conditions of exercise of fasciatherapy such as the implication of the practitioner $(n=4,1.7 \%)$, the necessity to work in a quiet environment ( $n=7,2.9 \%)$, or the too big difference between physiotherapy and fasciatherapy $(\mathrm{n}=13,5.5 \%)$ are less widely put forward and do not seem to be obstacles to exercising fasciatherapy within a physiotherapy practice. 


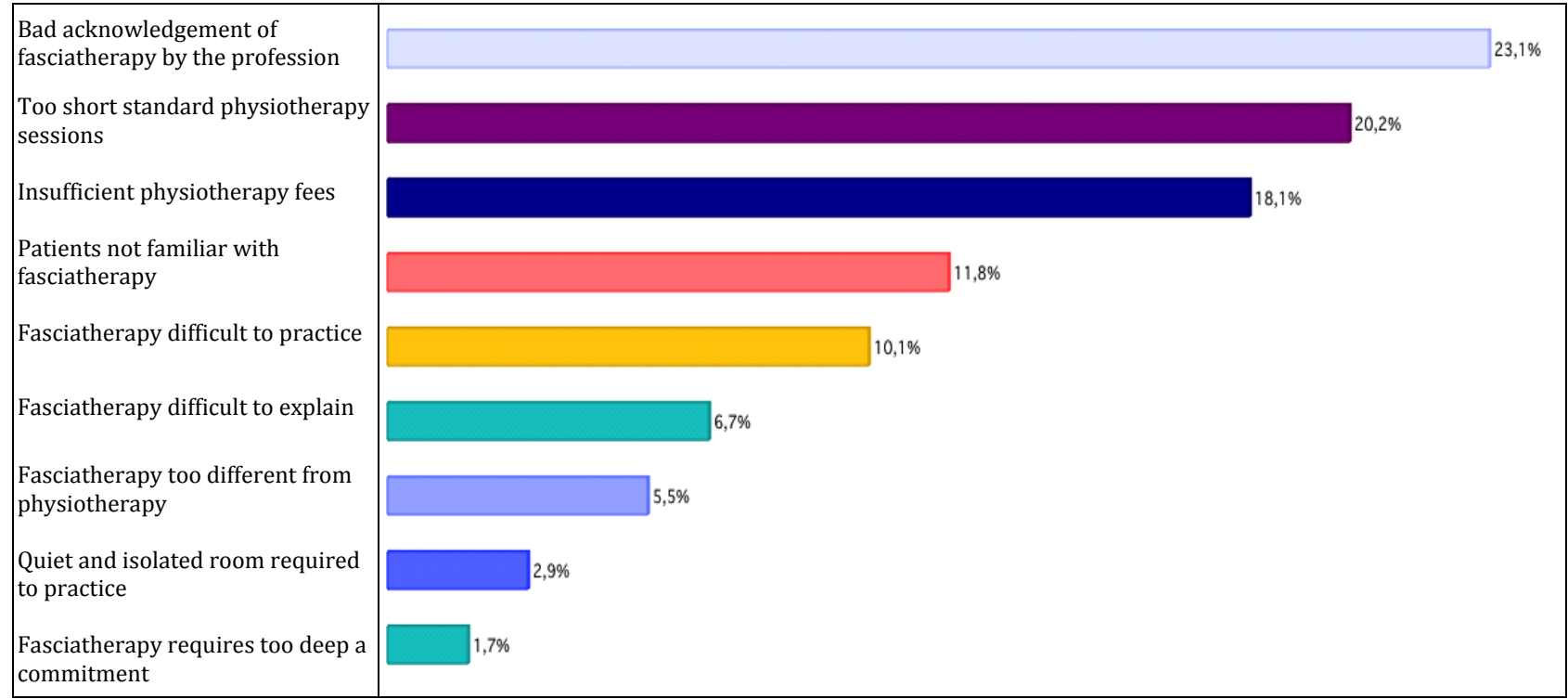

Figure 1. Main Difficulties Met to Apply Fasciatherapy in the Daily Physiotherapy Practice (Results of Choice 1 Among a Selection of Four Suggested Answers).

\section{Changes in the Professional Framework of Exercise}

Two thirds of the population ( $\mathrm{n}=158,66.4 \%$ ) mention changes operated in order to practice fasciatherapy. The most important ones are the creation of a private practice ( $n=161,67.7 \%$ ), the passage of a locum or assistant position to a private activity ( $\mathrm{n}=68,28.5 \%$ ) and the passage from an under contract practice to one without contract $(n=62$, $25.9 \%)$. Only one third of the population $(n=80$, $33.6 \%$ ) declare that they have not changed anything to their frame of exercise.

\section{Changes in the Care of Patients}

The majority of the population show that exercising fasciatherapy has been an opportunity to strengthen a practice which favours individualized care of the patients ( $n=197,82.8 \%$ ) or the opportunity to move from the care given to several patients at the same time to one patient at a time $(\mathrm{n}=36,15.1 \%)$.

Almost all the group sample also admit developing a more global care of the patient $(\mathrm{n}=199,83.6 \%)$ but also more pedagogical $(\mathrm{n}=108,45.3 \%)$ and to a lesser extent, more psychological one $(n=57,23.9 \%)$. Only a small proportion claim that fasciatherapy has led them to practice with a strictly therapeutical aim (n $=17,7.1 \%$ ). Only a small number of people declare that fasciatherapy has not changed anything in regards to their care orientation ( $\mathrm{n}=10,4.2 \%$ ).

A bit more than half of the population $(n=130$, $54.6 \%)$ declare they have developed a care in new fields. An analysis of the responses in the different fields as quoted by the respondents supplies the authors with the following results: pediatry ( $\mathrm{n}=46$, 19.3\%) and oncology $(n=39,16.4 \%)$ are the most frequently quoted, ahead of stress management ( $\mathrm{n}=$ $35,14.7 \%)$, pregnancy support and pelvi-perineology $(\mathrm{n}=28,11.8 \%)$, patients' education $(\mathrm{n}=27,11.3 \%)$, and sport $(n=23,9.6 \%)$.

Lastly, three quarters of the population ( $\mathrm{n}=180$, 75.6\%) have noticed a change of patients with fasciatherapy (see Figure 2). Their most common new 


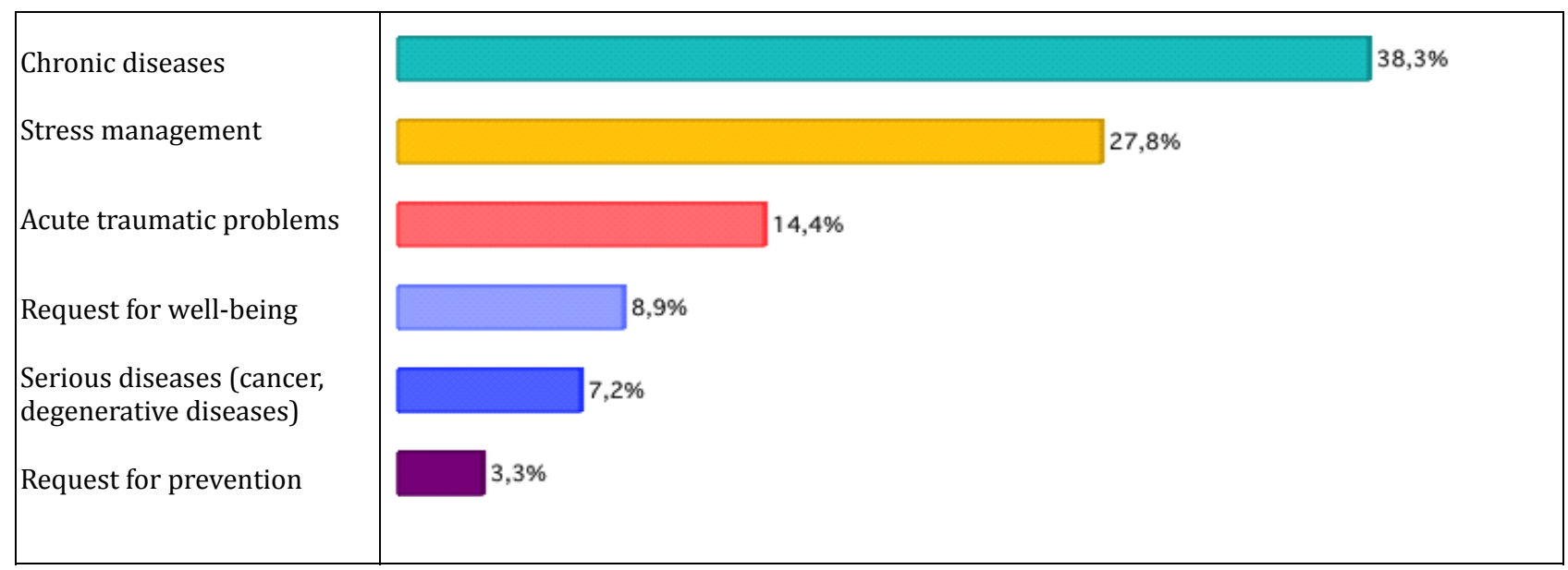

Figure 2. Rankings of the New Patients' Six Propositions Most Frequently Brought by Fasciatherapy (Choice 1-Percentage of Respondents).

patients are those who suffer from chronic conditions $(\mathrm{n}=69,38.3 \%)$ ahead of stress management $(\mathrm{n}=50$, $27.8 \%)$, acute traumatic problems $(n=26,14.4 \%)$, well-being ( $\mathrm{n}=16,8.9 \%)$, serious illness $(\mathrm{n}=13$, $7.2 \%)$, and prevention $(\mathrm{n}=6,3.3 \%)$.

\section{Impacts on the Orientation of Professional Training}

The rate of continuous training in physiotherapy decreases by 25.2 points after the fasciatherapy training. It moves down from $60.5 \%(n=144)$ of the respondents before the training to $35.3 \%(n=84)$ after. The main part of this training rate decrease is due to a decrease in the training for manual techniques and postural and gymnastic techniques which respectively loses 28 and six points of percentage of respondents (see Figure 3). This decrease could show that the masseurs-physiotherapists trained in fasciatherapy are fully satisfied of the evolution of their touch and do not try to undertake any other training in this field.

\section{Improvements in the Professional Practice}

The major part of the population (between $79 \%$ and 96\%) think that fasciatherapy has contributed to improving their therapeutic efficiency, their relationship to their patient, and their teaching skills considerably or even very considerably. In the same proportion, they also declare a substantial or even very substantial improvement of the healthcare they provide to physical pain, psychological suffering, acute and chronic diseases, and the quality of life and well-being (see Table 1).

The score mode (the highest number) is positioned on rank 3 (significant improvement) and the medium (50\% of the respondents) is also positioned on rank 3 for the eight examined variables, which confirms an average trend of answers to score 3 on all these variables.

The added frequencies of scores 3 and 4 for each variable (total of percentage for the answers to scores 3 and 4 ) range between $79 \%$ and $96 \%$ highlighting the widely acknowledged improvement for the examined variables.

All the respondents also claim that they acknowledge an improvement on at least one disease (only one person answered she had not noticed any improvement) while slightly more than half, 54\%, claim that they do not have any improvement on at least one disease. 


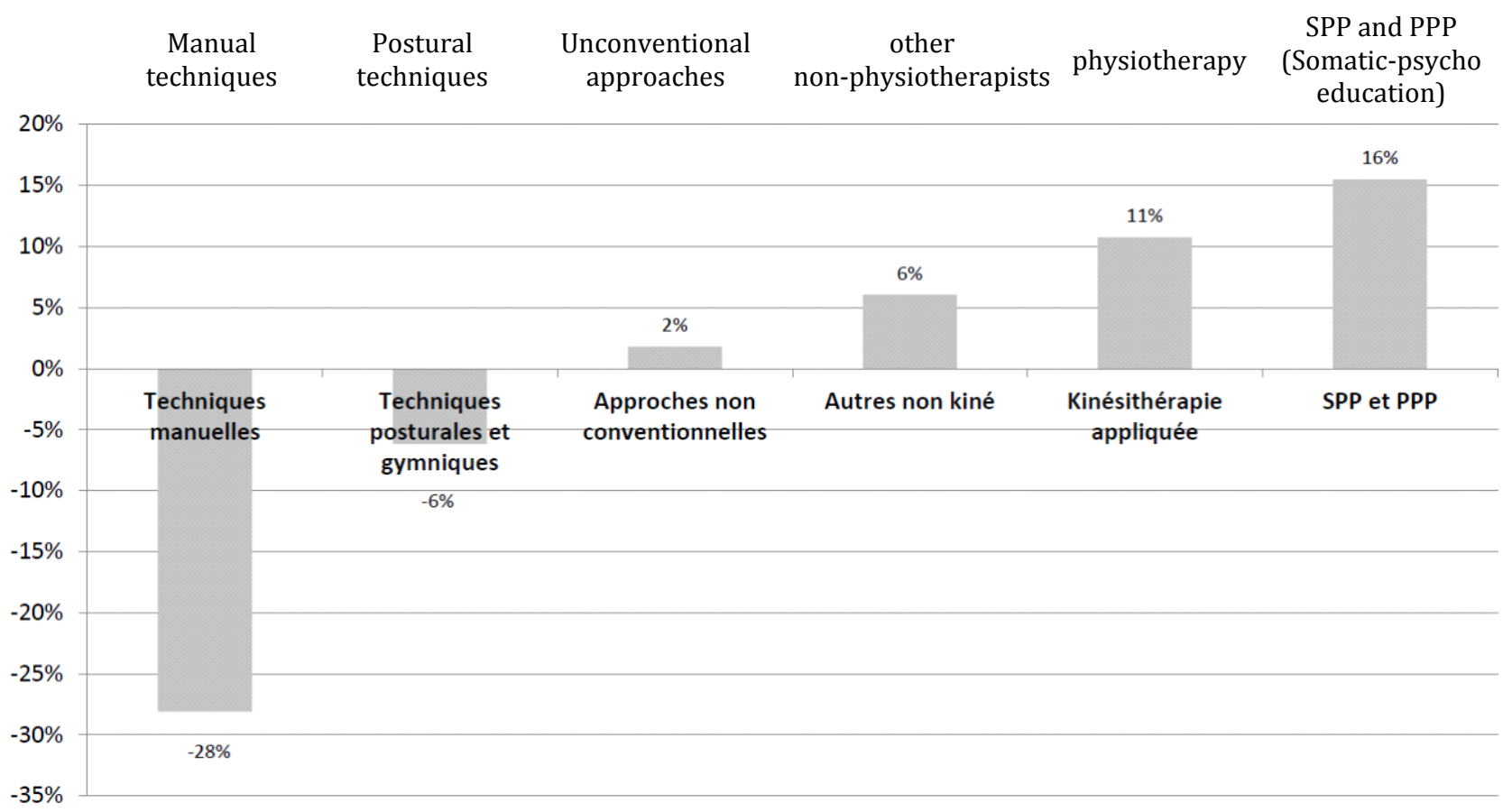

Figure 3. Evolution of the Respondents' Declared Professional Training Rate After Their Fasciatherapy Training, as Expressed in Differences of Percentage Points as Compared to the Declared Rate Before Training.

Table 1. Distribution of the Frequency of Responses to Questions About Noticed Improvements in the Main Three Business Sectors of Physiotherapy and in the Five Main Fields of Healthcare in Physiotherapy

\begin{tabular}{|c|c|c|c|c|c|c|c|c|c|c|c|}
\hline \multicolumn{2}{|c|}{ Examined variables } & \multicolumn{2}{|c|}{$\begin{array}{c}\text { No } \\
\text { improvement } \\
(1) \\
\end{array}$} & \multicolumn{2}{|c|}{$\begin{array}{c}\text { Little } \\
\text { improvement } \\
(2) \\
\end{array}$} & \multicolumn{2}{|c|}{$\begin{array}{c}\text { Significant } \\
\text { improvement } \\
(3) \\
\end{array}$} & \multicolumn{2}{|c|}{$\begin{array}{c}\text { Very significant } \\
\text { improvement } \\
(4)\end{array}$} & \multirow{2}{*}{\multicolumn{2}{|c|}{$\begin{array}{r}\text { Total } \\
\%\end{array}$}} \\
\hline & & $\mathrm{N}$ & $\%$ & $\mathrm{~N}$ & $\%$ & $\mathrm{~N}$ & $\%$ & $\mathrm{~N}$ & $\%$ & & \\
\hline \multirow{3}{*}{$\begin{array}{l}\text { Business } \\
\text { sector }\end{array}$} & Therapeutic efficiency & 0 & 0 & 12 & 5.0 & 125 & 52.5 & 101 & 42.4 & 238 & 100 \\
\hline & Relationship with patient & 3 & 1.3 & 36 & 15.1 & 122 & 51.3 & 77 & 32.4 & 238 & 100 \\
\hline & Teaching skills & 8 & 3.4 & 41 & 17.2 & 122 & 51.3 & 67 & 28.2 & 238 & 100 \\
\hline \multirow{5}{*}{$\begin{array}{l}\text { Healthcare } \\
\text { fields }\end{array}$} & Physical pain & 0 & 0 & 10 & 4.2 & 144 & 60.5 & 84 & 35.3 & 238 & 100 \\
\hline & Psychological suffering & 2 & .8 & 36 & 15.1 & 105 & 44.1 & 95 & 39.9 & 238 & 100 \\
\hline & Acute diseases & 2 & .8 & 48 & 20.2 & 126 & 52.9 & 62 & 26.1 & 238 & 100 \\
\hline & Chronic diseases & 1 & .4 & 28 & 11.8 & 138 & 58.0 & 71 & 29.8 & 238 & 100 \\
\hline & $\begin{array}{l}\text { Well-being and quality of } \\
\text { life }\end{array}$ & 2 & .8 & 19 & 8.0 & 122 & 51.3 & 95 & 39.9 & 238 & 100 \\
\hline
\end{tabular}

Note: Collected answers on a Likert scale: 1 no improvement, 2 little improvement, 3 significant improvement, and 4 very significant improvement.

The spinal $(\mathrm{n}=183,76.9 \%)$ and non-spinal $(\mathrm{n}=$ 99, 64.3\%) musculo-skeletal diseases, the most usual fields physiotherapy deals with are the most frequently quoted before the skull-based diseases are quoted by half of the respondents $(n=149,62.6 \%)$ and the visceral diseases are quoted by half of the respondents ( $n=126,53 \%)$. Pain syndromes, malaise and stress are less frequently quoted since only one 
Table 2. Quotation Frequency of the Most Improved and the Little or not Improved Diseases (Percentage of Respondents)

\begin{tabular}{lllll}
\hline \multirow{2}{*}{ Diseases } & Improved & \multicolumn{3}{l}{ Not improved } \\
\cline { 2 - 5 } & $\mathrm{N}$ & $\%$ & $\mathrm{~N}$ & $\%$ \\
\hline Spinal & 183 & 76.9 & 33 & 13.9 \\
Non-spinal musculo-skeletal & 99 & 64.3 & 62 & 26.1 \\
Skull-based & 149 & 62.6 & 31 & 13 \\
Visceral & 126 & 53 & 10 & 4.2 \\
Pain symptoms & 69 & 29 & 16 & 6.7 \\
Angst and stress & 56 & 23.5 & 11 & 4.6 \\
\hline
\end{tabular}

Depth
Ability to listen and be present
Relationship with the patient
Precise therapeutical gesture
Wholesomeness feeling
Therapeutical efficacy
Pleasure to touch
Capacity to be touched
Anatomy knowledge
Technical skill

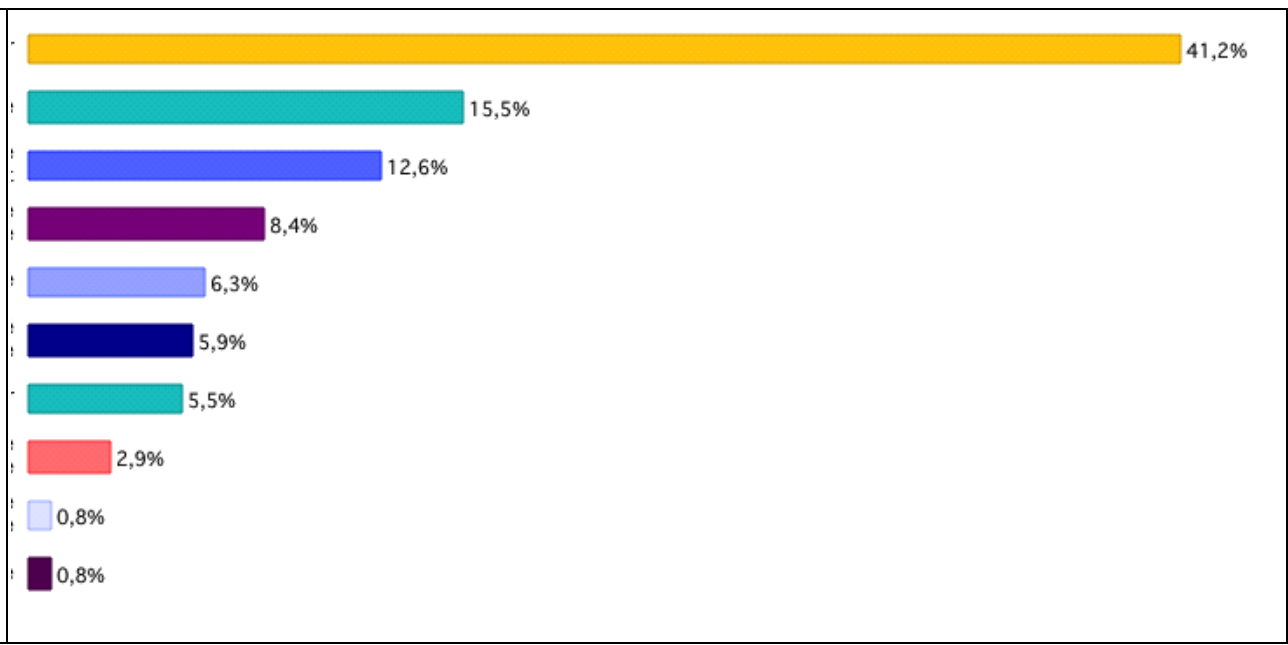

Figure 4. Rankings of the Elements of Touch Considered as the Newest and the Most Enriching for Professional Practice (Choice 1). Percentage of Respondents.

fourth of the practitioners mention them (respectively $\mathrm{n}=69,29 \%$; and $\mathrm{n}=56,23.5 \%$ ) (see Table 2).

\section{Professional Practice Enrichment}

Amongst the 10 dimensions of the touch the respondents were to choose from (see Figure 4), depth was the newest and the most enriching dimension for the professional practice $(n=98,41.2 \%)$. It was ranked far ahead of the ability to listen and to be present $(\mathrm{n}=$ $37,15.5 \%$ ), the ability to get in touch with the patient ( $n=30,12.6 \%$ ), or the accuracy of the therapeutic gesture $(n=20,8.4 \%)$.

Amongst the eight interpersonal qualities suggested to the respondents (see Figure 5), presence ( $\mathrm{n}=70,29.4 \%)$, listening skill $(\mathrm{n}=39,16.4 \%)$, attention $(\mathrm{n}=35,14.7 \%)$, and depth $(\mathrm{n}=32,13.4 \%)$ are the most frequently quoted as choice 1 , that is to say, they are considered as having been the most enriched in contact with fasciatherapy practice. Confidence $(\mathrm{n}=19,8 \%)$, gentleness $(\mathrm{n}=16$, $6.7 \%)$, adaptability ( $\mathrm{n}=15,6.3 \%)$, and stability $(n=12,5 \%)$ are the least often quoted in choice 1 . The first three elements concern directly the interpersonal dimension while the last four refer more to the relation practitioners nurture towards themselves.

\section{Sense of Professional and Personal Fulfilment}

The analyses of variance conducted on the responses (Likert scores) concerning the impacts of fasciatherapy 


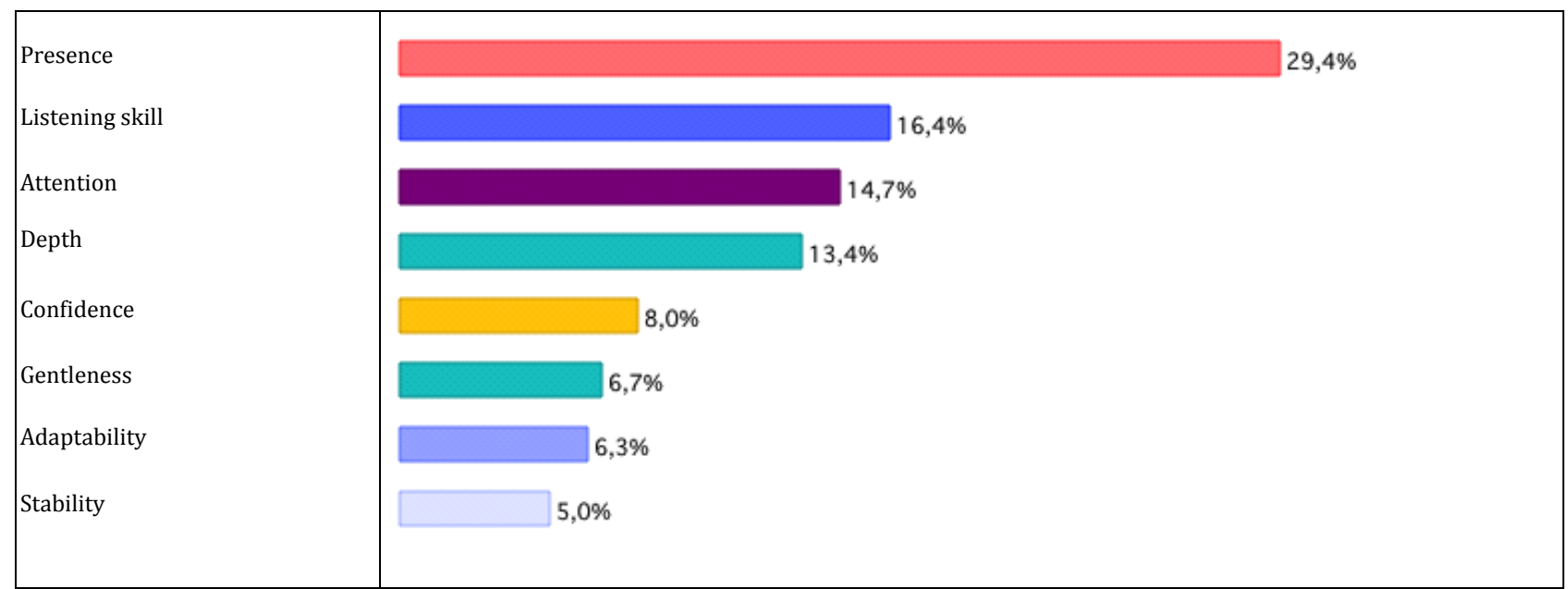

Figure 5. Rankings of the Interpersonal Qualities Considered as Acquired or Developed With the Exercise of Fasciatherapy (Choice 1). Percentage of Respondents.

Table 3. Analysis of Variance of the Responses Concerning the Representations of Fasciatherapy Practice (Fisher's Exact Test, $p=.001$ )

\begin{tabular}{|c|c|c|c|}
\hline & Average & $\begin{array}{l}\text { Level of significance and sense of the deviation } \\
\text { from the average }\end{array}$ & Value of $\mathrm{F}$ \\
\hline Improve my physiotherapy practice & 3.58 & +++++ & 5.58 \\
\hline Exercise a physiotherapy which is like me & 3.563 & +++++ & 8.46 \\
\hline Find the meaning of my physiotherapist's job & 3.319 & ++ & 3.69 \\
\hline Diversify my professional practice & 3.21 & . & 11.11 \\
\hline Live up a passion & 3.126 & . & 9.53 \\
\hline Stand out from the others & 2.66 & - & 12.98 \\
\hline Make a better living & 2.319 & $-\ldots$ & 7.79 \\
\hline General average of the scores & 3.111 & & \\
\hline
\end{tabular}

Notes: The significance of individual deviations is symbolized by the signs "+" or "-" (higher or lower than the average). The number of repeated signs shows the number of times when the significance threshold of $5 \%$ was exceeded, showing a kind of force of the significance of the deviation. The symbol "." shows a lack of deviation from the average.

on professional and personal life make it possible to characterize and classify the relative significance of the various natures of estimated impacts.

The surveyed agree to say that fasciatherapy is for them a means to improve their physiotherapy practice, that it enables them to practice physiotherapy in a way which looks like them and that it enables them to find the sense to their job. Conversely, they disagree to say that fasciatherapy would be a means to make a better living or to stand out among their fellow physiotherapists (see Table 3).

They also agree to consider that fasciatherapy provides them with more pleasure to practice (3.45), adds more value to their work (3.273), generates a new motivation (3.294), and offers them the possibility to discover what kind of physiotherapist they would like to be (3.273). Conversely, they do not agree as much on declaring that fasciatherapy is an opportunity to discover a new vocation or to find their place in their profession (see Table 4). 
Table 4. Analysis of Variance of the Responses Concerning the Influences of Fasciatherapy on Professional Life (Fisher's Exact Test, $p=.001$ )

\begin{tabular}{llll}
\hline Terms & Average & $\begin{array}{l}\text { Level of significance and sense of the deviation } \\
\text { from the average }\end{array}$ & Value of F \\
\hline More pleasure to practice & 3.45 & +++ & 13.57 \\
New motivation & 3.294 & + & 18.96 \\
$\begin{array}{l}\text { Discover what kind of physiotherapist I want to } \\
\text { be }\end{array}$ & 3.273 & + & 19.45 \\
Add value to my practice & 3.273 & + & 9.62 \\
More implication and more & 3.126 & - & 3.14 \\
commitment/dedication & 2.903 & -- & 18.62 \\
A real professional vocation & 2.861 & -- & 11.12 \\
Find my place in the profession & 3.169 & &
\end{tabular}

Notes: The significance of individual deviations is symbolized by the signs "+" or "-" (higher or lower than the average). The number of repeated signs shows the number of times when the significance threshold of $5 \%$ was exceeded, showing a kind of force of the significance of the deviation. The symbol "." shows a lack of deviation from the average.

Table 5. Analysis of Variance of the Responses Concerning the Influences of Fasciatherapy on the Development of Personal and Social Skills (Fisher's Exact Test, $p=.001$ )

\begin{tabular}{|c|c|c|c|}
\hline Terms & Average & $\begin{array}{l}\text { Level of significance and sense } \\
\text { of the deviation from the average }\end{array}$ & Value of $\mathrm{F}$ \\
\hline $\begin{array}{l}\text { Be more conscious of myself and of who I am } \\
\text { deeply as a human being }\end{array}$ & 3.378 & ++ & 12.35 \\
\hline Ability to relate to others & 3.277 & + & 9.33 \\
\hline $\begin{array}{l}\text { More flexible and more adaptable when } \\
\text { confronted to events of life }\end{array}$ & 3.176 & . & 12.02 \\
\hline Richer, fuller, and deeper life & 3.155 & . & 16.23 \\
\hline More conscious of my needs and my limits & 3.126 & . & 10.94 \\
\hline More self-confident & 3.101 & . & 16.48 \\
\hline Better self-esteem & 3.084 & . & 10.92 \\
\hline $\begin{array}{l}\text { Ability to find solutions when confronted to the } \\
\text { difficulties of everyday life }\end{array}$ & 2.996 & - & 10.97 \\
\hline $\begin{array}{l}\text { Developing joie de vivre and aspiration to } \\
\text { happiness }\end{array}$ & 2.845 & -- & 12.14 \\
\hline General average of scores & 3.127 & & \\
\hline
\end{tabular}

Notes: The significance of of individual deviations is symbolized by the signs "+" or "-" (higher or lower than the average). The number of repeated signs shows the number of times when the significance threshold of $5 \%$ was exceeded, showing a kind of force of the significance of the deviation. The symbol "." shows a lack of deviation from the average.

On a professional level, they rather agree to say that fasciatherapy has had a positive impact on their personal development (general average of scores $=3.127$ ). However, they significantly rather agree to say that it has mainly allowed them to be more conscious of themselves (3.378) and to develop their ability to relate to others (3.277). Conversely, they significantly agree less to say that fasciatherapy has developed their ability to find solutions and improved their joie de vivre (love of life) (see Table 5). 
Table 6. Analysis of Variance of the Responses Concerning the Influences of Fasciatherapy on Physical and Psychological Health (Fisher's Exact Test, $p=.001$ )

\begin{tabular}{|c|c|c|c|}
\hline Terms & Average & $\begin{array}{l}\text { Level of significance and sense } \\
\text { of the deviation from the average }\end{array}$ & Value of $\mathrm{F}$ \\
\hline Tool to manage tensions & 3.34 & & 10.28 \\
\hline Tool to solve stressful situations & 3.185 & & 55.67 \\
\hline Calmer and more peaceful & 3.122 & & 9.84 \\
\hline Less stressed & 3.076 & & 16.43 \\
\hline Pains and psychological tensions relief & 3.021 & & 20.77 \\
\hline Psychological well-being & 3.013 & & 22.33 \\
\hline Global better health & 2.924 & & 18.84 \\
\hline Less tired and better vitality & 2.882 & & 8.57 \\
\hline General average of scores & 3.07 & & \\
\hline
\end{tabular}

Notes: The significance of of individual deviations is symbolized by the signs "+" or "-" (higher or lower than the average). The number of repeated signs shows the number of times when the significance threshold of $5 \%$ was exceeded, showing a kind of force of the significance of the deviation. The symbol "." shows a lack of deviation from the average.

\section{Impacts on Physical and Psychological Health}

The analysis of variance of Likert's scores given to the suggested answers shows that the respondents generally agree to say that fasciatherapy has had a positive impact on their physical and psychological health (general average of scores $=3.07$ ). However, what emerges significantly is that fasciatherapy is above all a tool which enables them to manage their tensions (3.34) and to solve stressful situations (3.185) (see Table 6).

Practitioners resort to fasciatherapy sessions for themselves about seven times a year (standard deviation of 6.59 with a wide amplitude of responses from 0 to 40 sessions a year). The authors must notice however that:

(1) The $89 \%$ of the respondents resort to fasciatherapy sessions for themselves at least once a year, which means 207 people;

(2) The reason for fasciatherapy sessions (see Figure 2) is mainly:

(a) For physical pains and tensions (35.6\% out of the 207 practitioners);

(b) For well-being and stress (28.5\% out of the 207 practitioners);

(c) And for personal and professional development
(22.2\% out of the 207 practitioners).

\section{Impacts on Professional Identity}

More than two thirds of the sample $(n=153,64.3 \%)$ say that they consider themselves as physiotherapists-fasciatherapists and more than one quarter ( $n=65,27.3 \%$ ) claim that they are exclusively fasciatherapists. Only a small part of this group $(\mathrm{n}=$ 20, 8.4\%) consider themselves as physiotherapists only. These figures show that almost all the sample (n $=218,91.6 \%$ ) associate fasciatherapy to their professional identity (physiotherapists-fasciatherapists or fasciatherapists).

Beyond the self-perception as practitioners, more than half of the population present themselves professionally as physiotherapists and fasciatherapists while a much smaller part $(\mathrm{n}=25,10.5 \%)$ appear publicly as fasciatherapists. Conversely, more practitioners $(n=50,21 \%)$ claim that they are physiotherapists. The authors can notice that some practitioners $(\mathrm{n}=23,9.7 \%)$ display other methods (osteopaths, physiotherapists-osteopaths...).

It appears that the number of respondents introducing themselves as physiotherapists is higher 
than those who perceive themselves as such. Conversely, it is just as clear that the number of respondents introducing themselves as fasciatherapists is obviously lower than those who perceive themselves as fasciatherapists. However, the major part of the population ( $\mathrm{n}=165,69.3 \%$ of the respondents) display publicly their fasciatherapist identity.

Finally, when the surveyed are asked about the way they contemplate their professional future, more than half of them $(n=134,56.3 \%)$ see themselves with a status of physiotherapist specialized in fasciatherapy. More than a quarter $(n=59,24.8 \%)$ see themselves becoming exclusively fasciatherapists while a smaller part of them $(n=45,18.9 \%)$ see themselves exercising fasciatherapy within the framework of physiotherapy. These figures show that a wide proportion of practitioners $(n=193,81.1 \%)$ wish their fasciatherapist identity to be recognized.

\section{CONCLUSIONS}

As the authors mentioned it in the introduction, massage-physiotherapy is a multiform profession whose specific identity is based on the interpersonal dimension of touch, which implies an individualized approach of the patient. The results of this survey clearly illustrate that the practitioners who practice fasciatherapy are trying to develop and enrich this identity, regarding their motivations to training in this method in which they find a therapeutical efficacy, a consideration for body-mind unity, and the relational dimension of touch. The results also confirm that these physiotherapists are dissatisfied with their initial competence of touch and try to solve this identity dilemma through further professional trainings. Learning then practicing fasciatherapy seems to constitute a real crossroads within the context of this enrichement quest of the interpersonal dimension of touch since the authors' population is less trying to train to other manual approaches during or/and after their fasciatherapy training.

The therapeutical efficacy benefit associated with the development of relational competences and the reinforcement of individualized care of the patient attributed to fasciatherapy is likely to constitute essential explanatory factors of these results but the authors notice that the discovery of the touch's depth widely considered as the most enriching could constitute the missing dimension looked for by these professionals in the course of their professional life and their various previous trainings.

Given that the surveyed population have an fundamental indentity affinity with manual therapy, the integration of fasciatherapy in their practice of massage-physiotherapy would logically not cause too much trouble. Fasciatherapy has become an integral part of the daily professional practice: it even seems to be the reference technique or even the main technique of the activity for more than half the population (they perform more than five sessions per day) while for the others, it remains an adjuvant or a complement just as any other approaches (they perform less than five sessions per day).

The major organizational difference with massage-physiotherapy lies in the fact that fasciatherapy sessions last amost always longer than the conventional duration (more than 30 minutes). The difficulties met (lack of time, and low fees for a physiotherapy session) are inherent in the constraints imposed by the conventional framework of massage-physiotherapy. To meet these constraints, practitioners adapt their practice and a large number of them are led to practice fasciatherapy outside their physiotherapy session, even outside the conventional framework.

Although the profession of masseurs-physiotherapists is not the healthcare profession, the most vulnerable to professional risks and practitioners are rather satisfied with their job and their image, excess work and lack of recovery can make this job difficult at a physical as well as 
psychological level. The results of the survey on this point show that practicing fasciatherapy has a positive impact on the quality of life at work since one can notice increased pleasure and motivation to practice and a higher self-actualization of the job. Although fasciatherapy does not suppress tiredness, stress at work, or diseases, it helps living a more relaxed professional routine. It constitutes a means to manage and face these job-related daily professional tensions and stress.

The authors also evoked the double essential notions for careproviders and the importance to combine caring and curing with the necessity to adapt treatments to meet the evolution facing chronic diseases. On this issue, fasciatherapy, as it is rooted in a sensible approach of care, favours the development of the interpersonal and educational dimension of care. The results of the authors' survey illustrate that masseurs-physiotherapists who practice this approach develop a more pedagogical and more complete approach of their patients and move away from an exclusive therapeutical aim. This new way of taking care of patients reinforces their feeling of efficacy and leads them even to develop their activity in the domain of chronic diseases, stress, psychological suffering, and quality of life. The practice of fasciatherapy seems to help masseurs-physiotherapists face the intricate situations in which they would frequently feel powerless, which would cause exhaustion and uneasiness. This assessment is reinforced by the fact that fasciatherapy favours personal and interpersonal development, especially by a greater self-consciousness and a better capacity to relate to others which form the base of the healthcarer's identity and protect them against tiredness (weariness) and professional exhaustion.

In this context, it is quite logical that the surveyed population would express a feeling of professional achievement (improvement, pleasure, satisfaction, and motivation). The results also show significantly that practicing fasciatherapy gives meaning to the job. This trend can be observed in the responses showing that the practitioners feel they practice a kind of physiotherapy which looks like them and discover what physiotherapists they have always wanted to be since they started practicing fasciatherapy. This congruence between personal and professional identities constitutes according to the authors a fundamental contribution to the surveyed's identity construction. As a matter of fact, the authors' population, just like the reference population is as a whole satisfied of their job (only one fourth of the population declared that they trained in fasciatherapy to find a meaning and a professional motivation). In this context, fasciatherapy seems to contribute to building and/or reaching some sort of professional ideal whose absence or loss is source of existential suffering.

This positive impact on professional life can be witnessed in the large proportion of the population who start their own private practice (although they remain attached to group practice), engage in a private way of exercising, and in a less important way choose a non-conventional way of practicing and as they do so displaying self-confidence, a desire to take action and a will to assert their identity.

As a consequence, it is logical that practicing fasciatherapy impacts the perception that masseurs-physiotherapists have of their professional identity. Reading the results allows the authors to draw two great patterns of professional reconfiguration (the authors do not take into account the $8 \%$ who do not associate fasciatherapy to their identity). The majority of the popultaion tend to associate fasciatherapy to their physiotherapist's identity (64\% consider themselves as fasciatherapists and physiotherapists) considering that this approach is part of their identity (62.2\% consider that practicing fasciatherapy is practicing physiotherapy) and that it reinforces or specifies it $(52 \%$ consider it as a specialization or a competence). Another less important part deviate from physiotherapy and identify themselves exclusively as fasciatherapists 
considering fasciatherapy is a profession and a practice different from physiotherapy.

This survey shows that practicing fasciatherapy represents for a wide part of French masseurs-physiotherapists a way to find a deeper meaning to their job and their attachment to their manual physiotherapist identity by fulfilling their search for a deeper and more relational manual practice centred on the body-mind unity. It proves also that such an approach integrates well in the practice of physiotherapy as it meets the current demands of massage-physiotherapy (more efficacy, effective care of chronic diseases, and psychological suffering) and also contributes to personal and professional fulfilment. The surveyed masseurs-physiotherapists consider that this approach is an integral part of their job, but however, they consider it as a practice which reinforces and even changes their professional identity.

\section{References}

Angibaud, A. 2013. "La voie du corps sensible dans le traitement du mal être" (The Way of the Sentient Body in the Treatment of Unease). Revue Réciprocités 8:26-35.

Aumonier, B. 2017. “La pensée à l’épreuve de l'expérience du Sensible: analyse secondaire de données qualitatives et approche catégorielle anticipation/émergence innovante d'inspiration phénoménologique” (Impact of Experiencing Sentience on the Thinking Process: A Secondary Analysis of Qualitative Data and an Innovative Anticipation/Appearance Sectional Approach Inspired by Phenomenology). Recherches Qualitatives 20:355-367.

Austry, D. 2009. "Le touchant touché dans la relation au Sensible, une philosophie du contact” (The Touching Person Touched When in Touch With Sentience, a Philosophy of Contact). Pp. 137-166 in Sujet sensible et renouvellement du moi, les apports de la fasciathérapie et de la somato-psychopédagogie (Sentient Subject and Renewal of the Self, the Contributions of Fasciatherapy and Somatic Psychoeducation), edited by D. Bois, M.-C. Josso, and M. Humpich. Ivry-sur-Seine: Editions Point d'Appui.

Austry, D. and E. Berger. 2014. "Empathie, toucher et corps sensible: pour une philosophie pratique du contact" (Empathy, Touch and Sentient Body: For a Practical Philosophy of Contact). Pp. 229-246 in L'empathie, au carrefour des sciences et de la clinique (Empathy at the
Crossroads of Sciences and Clinic), edited by A. Besse, M. Botbol, and N. Garret-Gloanec. France: Doin Éditeurs.

Bertrand, I., D. Bois, M. C. Fédor, C. Leyssene-Ouvrard, M. Miolanne, and Y. Boirie. 2017. "Assessing Body-Centered Educational Approaches to the Management of Obesity." Obesity Open Acces 3(2):1-4.

Bois, D. 2007. "Le corps sensible et la transformation des représentations de l'adulte, Vers un accompagnement perceptivo-cognitif à médiation du corps sensible” (The Sentient Body and the Transformation of Adults' Representations to a Perceptual Cognitional Support via the Sentient Body). Thèse de doctorat européen (European doctoral thesis), Université de Séville, Département didactique et organisation des institutions éducatives, Espagne.

Bois, D. and D. Austry. 2007. "Vers l'émergence du paradigme du Sensible" (To the Emergence of the Paradigm of the Sensible). Revue Réciprocités 1:6-22.

Bois, D., H. Bourhis, and E. Berger. 2010. "L'approche somato-psychique dans le champ de l'éducation pour la santé: Analyse biographique du récit de vie d'un patient” (The Somatic Psychoeducational Approach in Health Education: A Biographical Analysis of a Patient's Life Story). Presented at Actes du congrès AREF 2010, September 13-16, Université de Genève, Symposiums Courts.

Bourhis, H. 2012. “Toucher manuel de relation sur le mode du Sensible et Intelligence sensorielle - Recherche qualitative auprès d'une population de somato-psychopédagogues" (Manual Touch of Contact Based on Sentience and Sensorial Intelligence. A Qualitative Research Amongst Somatic Psychoeducators). Thèse de doctorat en Sciences de l'Éducation (Doctoral thesis in Educational Sciences), Université Paris VIII.

Bourhis, H. and D. Bois. 2012. "O Tocar na Relação de Cuidado Baseada no Sensível” (On Touch of Contact in a Sentience-Based Caring Relationship). Educação \& Realidade 37(1):33-49.

Caisse d'Assurance et de Retraite des Pédicures, Infirmiers, Masseurs-Kinésithérapeutes et Orthophonistes (CARPIMKO). 2008. Enquête sur la pénibilité des auxiliaires médicaux (A Survey on the Strenuous Working Conditions of Medical Assistants). Synthèse.

Conseil National de l'Ordre des Masseurs-Kinésithérapeutes (CNOMK). 2009. Étude préalable aux États généraux de la profession. Rapport final (A Preliminary Survey for the Professional Convention. Final Report). Réalisé par Éliane Conseil, Santé sociale. Edité par l’Ordre des Masseurs-Kinésithérapeutes. Retrieved (http://cromk-centre. org/DOC/EG2010_EtudePrealable_200910.pdf).

- 2010. Questionnaire: Votre avis sur la 
masso-kinésithérapie aujourd'hui (A Questionnaire: Your Opinion on Massage-Physiotherapy Today). Edité par l’Ordre des Masseurs-Kinésithérapeutes.

- 2012. Avis CNO n²012-03. Avis du Conseil National de l'Ordre du 22 juin 202 Relatif à la «Fasciathérapie» (CNO Opinion no. 2012-03. Opinion of the National Council of the Order of 22nd June 202 Related to “Fasciatherapy”). Retrieved (http://rhone.ordremk.fr/files/2013/07/AVIS-DUCNO-DU-21-JUIN-2012-RELATIF-A-LA-FASCIATHER APIE.pdf).

Convard, C. 2013. "Fasciathérapie et anxiété sportive. Étude des effets de séances de fasciathérapie sur l'anxiété de 5 compétitrices en gymnastique rythmique” (Fasciatherapy and Sports Anxiety. A Study on the Results of Fasciatherapy Sessions on the Anxiety of 5 Competitors in Rhythmic Gymnastics). Master en Kinésithérapie sportive (Master's thesis in Sports Physiotherapy). Faculté des Sciences de la Santé, Université Fernando Pessoa, Porto, Portugal.

Courraud, C. 2007. "Fasciathérapie et relation d'aide. Le toucher psychotonique et son application sur la relation d'aide au patient en kinésithérapie” (Fasciatherapy and Helping Relationship. The Psychotonic Touch and Its Application on a Helping Relationship With Patients in Physiotherapy). Mains Libres, La Revue Romande de Physiothérapie 4:151-158.

— 2015. "Fasciathérapie et identité professionnelle. Étude des reconfigurations identitaires d'une population de masseurs-kinésithérapeutes pratiquant la fasciathérapie" (Fasciatherapy and Professional Identity. A Study of Identity Reconfigurations Amongst Physiotherapists Practicing Fasicatherapy). Thèse de Doctorat en Sciences Sociales-Spécialité psychologie (Doctoral thesis in Social Sciences-Specialization: Psychology). Université Fernando Pessoa. Retrieved (http://www.cerap.org/sites/ default/files/public-downloads/doctorats/These_Christian_ Courraud_2015_texte-seul_final.pdf).

Courraud, C. and N. Quéré. 2010. "La fasciathérapie: intérêts en kinésithérapie" (Fasciatherapy: Significance in Physiotherapy). Profession Kiné 24:10-14.

Cousin, V. 2016. “L’approche somatopédagogique de l'accompagnement: conditions d'émergence, repères épistémologiques, cohérence théorique et pratique” (The Somatic Psychoeducational Support Approach: Conditions of Emergence, Epistemological Landmarks, Theoretical and Practical Coherence). Mémoire de Mestrado en Psychopédagogie perceptive (Master's thesis in Perceptual Psychotherapy), Université Fernando Pessoa, Porto.

Cusson, A. 2015. "Enrichissement perceptif et sujet sensible. Traverser la difficulté perceptive” (Perceptual Enrichment and Sentient Subject. Overcoming Perceptual Problems). Pp.
279-300 in Identité, Altérité, Réciprocité. Pour une approche sensible de la formation, du soin et de l'accompagnement (Identity, Alterity, Reciprocity. For a Sentient Approach of Training, Curing and Supporting). Vol. 2, edited by D. Austry, E. Berger, K. Grenier, and D. Léger. France: Editions Point d'Appui.

Dagot, D. 2013. "Développement du leadership et exercices de soi explicites” (Developing Leadership and Meaningful Exercises of the Self). Revue Réciprocités 7:34-41.

Daloz, L. 2007. "Epuisement professionnel et blessures de l'idéal. Réflexions cliniques sur la désillusion des soignants et la formation initiale" (Professional Exhaustion and Injuries of the Ideal. Clinic Reflections on the Careproviders' Disillusionment and Their Initial Training). Pédagogie Médicale 8(2):82-90.

Dupuis, C. 2016. “Combinaison d'approches quantitatives et qualitatives pour l'évaluation des effets de la fasciathérapie méthode Danis Bois sur la douleur de patients fibromyalgiques” (Combining Quantitative and Qualitative Approaches to Assess the Effects of Danis Bois Method Fasciatherapy on the Suffering of Patients With Fibromyalgia). Recherches Qualitatives 20:515-530.

Duval, T., E. Duprat, and E. Berger. 2013. "Fasciathérapie et transformation du rapport à la santé” (Fasciatherapy and Transformation of the Relation to Health). Revue Réciprocités 8:45-55.

Florenson, M. H. 2012. L'émergence du Sujet Sensible (The Emergence of the Sentient Subject). France: Editions Point d'Appui Sciences.

Gatto, F. 2005. Éduquer la santé (Educating Health). Paris: Éditions L'Harmattan.

Gauthier, J. P. 2015. "L’expérience de la joie ontologique” (Experiencing Ontological Bliss). Pp. 301-321 in Identité, altérité, réciprocité. Pour une approche sensible de la formation, du soin et de l'accompagnement (Identity, Alterity, Reciprocity. For a Sentient Approach of Training, Curing and Supporting). Vol. 2, edited by D. Austry, E. Berger, K. Grenier, and D. Léger. France: Editions Point d'Appui.

Groupe Pasteur Mutualité. 2011. Baromètre des professionnels de santé (A Barometer of Health Professionals). Sondage Viavoice pour le groupe Pasteur Mutualité (A Viavoice Survey for the Pasteur Mutualité Group).

Hesbeen, W. 1997. Prendre soin à l'hôpital, inscrire le soin infirmier dans une perspective soignante (Providing Care at the Hospital, Entering Nursing Care Into a Curing Perspective). Paris: Éditions Masson.

Holcman, R. 2006. "L’ordre sociologique, élément structurant de l'organisation du travail. L'exemple des bureaucraties professionnelles: ordre soignant contre ordre dirigeant à l'hôpital” (The Sociological Order, Structuring Element of 
Work Organization. The Example of Professional Bureaucracies: Curing Order vs. Managing Order at the Hospital). Thèse de doctorat de Sciences de gestion (Doctoral thesis in Management Sciences). Conservatoire National des Arts et Métiers (CNAM).

Honoré, B. 2003. Pour une philosophie de la formation et du soin (For a Philosophy of Training and Curing). Paris: Éditions L'Harmattan.

Humpich, M. and G. Lefloch-Humpich. 2008. "L’émergence du sujet sensible: itinéraire d'une rencontre au coeur de soi” (The Emergence of a Sentient Subject: Itinerary of a Meeting Within the Heart of the Self). Revue Réciprocités 2:19-34.

Kwong, E. H. and T. W. Findley. 2014 "Fascia-Current Knowledge and Future Directions in Physiatry: Narrative Review.” J Rehabil Res Dev 51(6):875-884.

Kynos. 2012. Modalisa 7.0. Logiciel de traitement d'enquêtes par questionnaires et entretiens depuis 1987 (Modalisa 7.0. A Survey Process Software Through Questionnaires and Interviews Since 1987). Édité par Kynos (Published by Kynos).

Laemmlin-Cencig, D. 2015. "La dimension soignante et formatrice en pédagogie perceptive. Le point de vue des personnes accompagnées en pédagogie perceptive” (The Curing and Training Dimension in Perceptual Education. The Viewpoint of People Supported by Perceptual Education). Thèse de doctorat en Sciences Sociales—option Psychopédagogie (Doctoral thesis submitted in Social Sciences-Specialization: Psychopedagogy). Université Fernando Pessoa, Portugal.

Lambert, S. 2013. "Fasciathérapie et ressources attentionnelles du golfeur. Effets d'une séance d'accordage somato-psychique sur la mobilisation des ressources attentionnelles de golfeurs amateurs” (Fasciatherapy and Attentional Resources of the Golf Player. Effects of a Somatic Psychoeducation Session on Gathering Amateur Golf Players' Attention Resources). Master en Kinésithérapie sportive (Master's thesis in Sports Physiotherapy), Faculté des Sciences de la Santé, Université Fernando Pessoa, Porto, Portugal.

Lassere-Moutet, A., J. Dupuis, M. Chambouleyron, G. Lagger, and A. Golay. 2008. "Transformer son identité professionnelle: impact d'un programme de formation continue de soignants en éducation thérapeutique du patient" (Transforming One's Professional Identity: Effects of a Care Provider's Continuing Education Program in Therapeutical Education of Patients). Revue de Pédagogie Medicale 9(2):83-93.

Marchand, H. 2015. "Pédagogie Perceptive et transition professionnelle-Etude des apports d'un dispositif d'accompagnement en Pédagogie Perceptive auprès de personnes ayant vécu un licenciement” (Perceptual Education and Professional Transition. A Study on the Contributions of a Perceptual Education Support Plan With Laid-off People). Thèse de Doctorat en Sciences Sociales-Spécialité psychologie (Doctoral thesis in Social Sciences-Specialization: Psychology). Université Fernando Pessoa. Retrieved (http://www.cerap.org/sites/ default/files/public-downloads/doctorats/These_Helene-Ma rchand_2015_complete-finale.pdf).

Matharan, J., J. Micheau, and E. Rigal. 2009. Étude sur le métier de masseur-kinésithérapeute (A Study on the Physiotherapist Profession). Rapport de l'Observatoire National de la Démographie des Professions de Santé (ONDPS).

Monet, J. 2011. "La kinésithérapie, une spécialité médicale impossible. Le métier de kinésithérapeute: une approche socio-historique, in Le livre vers... de la kinésithérapie” (Physiotherapy, an Impossible Medical Specialty. The Physiotherapist Profession: A Social Historical Approach, in the Book Towards.... Physiotherapy). Conseil National de l’Ordre des Kinésithérapeutes. Pp. 4-35.

Payrau, B., N. Quéré, M. C. Payrau, and E. Breton. 2015. "Faciatherapy and Reflexology, Compared to Hypnosis and Music Therapy in Stress Management.” Pp. 181-182 in Fascia Research IV, edited by S. Wearing, R. Schleip, L. Chaitow, W. Klingler, and T. W. Findley. Munich, Germany: Kiener Éditions.

Piguet, C. 2010. "L’autonomie dans les pratiques infirmières: une posture à clarifier au sein du système de sante" (Autonomy in Nursing Practices: A Position to Define Within the Health System). Presented at Actes du congrès de l'Actualité de la recherche en éducation et en formation (AREF), Université de Genève, September 2010.

Rosier, P. 2013. "La Fasciathérapie Méthode Danis Bois et la récupération physique, mentale et somato-psychique du sportif de haut niveau. Evaluation quantitative et qualitative auprès d'une population de sportifs de haut niveau” (Danis Bois Method Fasciatherapy and Physical, Mental and Somatic-Psychological Recovery of High Level Sports People. A Quantitative and Qualitative Evaluation Amongst High Level Sportsmen). Thèse de doctorat en Sciences Sociales, option Psychopedagogie (Doctoral thesis in Social Sciences-Specialization: Psychology). Porto, Portugal.

Rothier-Bautzer, E. 2002. "Pratiques soignantes en mutation: de la lutte contre la maladie à la collaboration avec le patient” (A New Kind of Curing Practice: Fighting Diseases With the Patients' Collaboration). Revue Française de Pédagogie 138:39-50.

- 2012. Entre cure et care. Les enjeux de la professionnalisation infirmière (Between Curing and 
Caring. The Stakes of Nursing Professionalization). Paris: Éditions Lamarre, Wolters Kluwer.

Schleip, R. and H. Jäger. 2012. "Interoception. A New Correlate for Intricate Connections Between Fascial Receptors, Emotion, and Self Recognition." In The Tensional Network of the Human Body, edited by R. Schleip, L. Chaitow, T. W. Findley, and P. Huijing. Fascia: Churchill Livingstone Elsevier.

Sicard, D. 2013. Les professions de santé au 1er janvier 2013 (Health Professions on January 1st, 2013). Direction de la Recherche, des études, de l'évaluation et des statistiques (DRESS). Retrieved (http://drees.solidarites-sante.gouv.fr/ IMG/pdf/seriestat183.pdf).

Simmonds, N., P. Miller, and H. Gemmell. 2012. "A Theorical Framework for the Role of Fascia in Manual Therapy.” $J$ Bodyw Mov Ther 16:83-93.

Tronto, J. C. 1993. Moral Boundaries: A Political Argument for an Ethic of Care. New York: Routledge Editors of
Taylor \& Francis Group.

Trudelle, P. 2003. "Lombalgie: enquête autour d'un consensus" (Low Back Pain: Investigating a Consensus). Kinésithérapie, Les annales 3(20-21):11-35.

\section{Bios}

Christian Courraud, Ph.D., director of CERAP/UFP, Clermont-Ferrand, France; research fields: professional identity, learning experiencing, fasciatherapy, health workers education, touch and relationship.

Anne Lieutaud, Ph.D., CERAP/UFP, Montpellier, France; research fields: paradigm shift, individual and collective transformation, sensorial perception and affects.

Danis Bois, Ph.D., CERAP/UFP, professor at University Fernando Pessoa, Porto, Portugal; research fields: human and social sciences, perceptual psychoeducation, phenomenological praxis. 